\title{
On Chris’s Unyielding Spirits Against Fate in The Pursuit of Happyness
}

\author{
BAO Ruo-jun \\ School of Foreign Languages, Jinan University, Guangdong, China
}

\begin{abstract}
The Pursuit of Happyness has always been a well-received film ever since its release in 2006. This film mainly describes how a black American worms his way from the bottom of the society to success. This paper intends to make a detailed description of the life experience of the main character, including his life obstacles and fighting. It also expounds on the image of the main character. Moreover, through the analysis of the reasons why Chris, an average American with his unyielding spirits, succeeds in seizing his happiness through sorrow and pain in life, the practical significance with regard to individual and social development is put into the limelight.
\end{abstract}

Keywords: unyielding spirit, happiness, fighting against fate, individual and social development

\section{Introduction}

This film The Pursuit of Happyness is directed by Gabriele Muccino. It is adapted from a famous American black investment expert Chris Gardner's autobiography, which is published in 2006. It is a true story of the great millionaire Chris Gardner, who started his business from scratch. The film is set in a special period of America, a time when the whole Americans were mired in the Great Depression, due to which workers were beset with unemployment and poor people were suffering from a poor living standard. More particularly, it is also a society whose social hierarchy is cruel and clear. People in America were faced with serious plight, impoverished by long-time unemployment, bankruptcy and poverty. They were all in great desire to shake off the abject poverty. Therefore, Americans began to fight against the crisis with great force to seek their own ways and this great force they show during the crisis becomes a symbol of American humanity. Especially during recent years, the American Dream has already become a popular theme, which has deeply imprinted on every American's heart. With the progress of the era, people assign the item a new meaning: a dream for personal development. American people, with this kind of dream, choose to challenge their fate with unyielding spirits to pursuit their final happiness on their own.

In this film, the main character Chris Gardener paints a blueprint when he gets married and makes a great deal of investments on the scanner. After more than ten years' hard work, he gains no return, which drives all his family members, especially his wife, crazy. For many times, he is defeated by the crucial reality driven by the merciless depression, however, he keeps moving ahead with his personal unyielding spirits. Having encroached on the upper ladder from nearly the lowest social level, Chris finally reaps lucrative rewards.

The analysis of this film not only shows us the unyielding spirits people need to have when fighting against life crisis, but also improves people's understanding on American Dream. In a narrower sense, this

BAO Ruo-jun, MTI, School of Foreign Languages, Jinan University. 
paper aims to tap the unyielding inner spirits of man, including persistence, optimism, and permanent belief. In a broader sense, this paper intends to explain American Dream which is successfully reflected by a small character. And finally, it gives some inspirations to Chinese about how to materialize Chinese dream.

\section{Image of the Main Character}

Feature analysis always presents people a distinctive and vivid image of the main character and provides convincing reasons for the main character's final destination. In this film, Chris Gardener is an inspirational figure who creates his own wonder in an ordinary American society, outstripping most people at his age. It may easily dawn on people the reason why such an insignificant person can stand out in the society of a mess.

Persistence is always a basic element for man's success. Chris is a person who never gives in in front of many obstacles. First, his unwise investment in the scanners drains his financial pools. Second, the financial problem drives his wife crazy and thus intensifies the fissure between them. Third, his wife intends to take away his son, who means everything for him. Fourth, the scanner is stolen for many times, which nearly puts him to death. Fifth, he gains an opportunity of training for six months in a brokerage with no salary, while the only life resource he possesses would be the six scanners, which are also hard to sell. Therefore, in front of him there lies a serious choice which may influence his future. Sixth, the government confiscates his assets, which drags his life to the hell. To make a living, he has to join the long queue waiting for a shabby shelter in a church and even to sell his blood to fix his broken scanner. His life seems to be filled with low ebbs. However, what on earth is the way he finally achieved the little part of his life called "happiness"? Persistence can account for this question.

Like a roller coaster, life can never be smooth all the time. Therefore, keeping an optimistic attitude toward the surroundings is of great importance for us. Chris is an optimistic man, who never surrenders in front of misfortunes or lets the negative emotions defeat him. Optimism finally brings luck to his life. A conversation between Chris and Mr. Thistle demonstrates the importance of being optimistic: "How are you doing?" "I am doing well, how are you getting along?” “Good, good, I am good.” Optimism brings him only a tiny hope to his life, but it functions as an effective driver for his success. In an age of economic crisis, desperation spreads everywhere. A flash of pessimism in people's mind may force them to give way to the crucial reality. Chris holds his optimism tightly so as to prevent himself from being trapped in the crisis.

Life calls for belief, which equals to the mental cure of a man in struggle and the source of his unyielding spirits. Belief is an indispensable part of American people's life. In 1776, Thomas Jefferson drafted The Declaration of Independence, which consists of three core beliefs: everyone is born to be equal; everyone has the right to pursue happiness; government should protect people's happiness and right, or people can overthrow it (Jefferson, 1776). It is these three beliefs that embolden all Americans to stand up and fight for their own bright future. Chris Gardener, edified by The Declaration of Independence, chooses to pursue his own happiness through his fighting against fate. He sticks to belief, which is always deeply rooted in the heart of every American. Moreover, his beliefs are testified by his action.

A man should be wise enough in his social interaction and working. Firstly, a wise man may know how to bring his superiority to the full play and avoid his weakness. At the beginning of the film, Chris asks a stockbroker how to be someone like him, "To be good with numbers and good with people". That is his motto and direction of starting a business. The luckiest thing is that Chris is exactly that kind of man. He shows witty remarks in front of his employers; he performs his talent of playing magic cube to attract employers; he shows 
his generosity to help his potential employers despite having almost no money in his wallet; he exhausts his wit and energy to stand out in the internship... All of these flesh up a man with wisdom both in interacting with others and during his internship. Most importantly, Chris is a man who knows what he is going to be and through which way he is bound to success. That is his biggest wisdom.

People are born with duty. Chris in this film is a man who holds strong responsibility both for his son and for the whole family. He wants to make the ends meet to live up to the promise he makes for his wife when they got married; he wants to make up for his son and to give him everything that a father can give; he wants to shake off poverty and to bring vigor to the whole family; he wants to realize his social value as an American... All these he does is for one purpose - to make a better life for his family. He is a man worthy of being admired, for he is both a good father and a good husband, the pillar of the whole family.

\section{Obstacles and Fighting}

This paper explores the obstacles and fighting of Chris and analyses the motivations for his fighting. Life is hard for Chris, in front of whom there stand many obstacles. Before he gets married, he lives a wretched life. His father abandons him when he is a little boy (Gardner, 2010). Therefore, memory about paternal love in his whole childhood is very dim. After getting married, Chris Gardener becomes a salesman who sells a special kind of medical instrument which is called bone density scanner. To support his family, he has to sell at least two bone density scanners to pay his house rent and his son's day care. This goal, small as it is, is still hard for him to reach because he can't even afford a formal nursery school. Therefore, both his wife and he must work laboriously to make ends meet. He even needs to pick up his kid every day because of his wife's tight schedule. However, diligent as Chris is, he still finds it difficult for him to sell the instrument. His wife at last chooses to leave him, for she can no longer endure the endless torture and hopeless future. Consequently, Chris has to raise his son alone and faces this crucial reality independently. Misfortune never comes singly. Every time he stands up and prepares to make some change, life always drags him back to his original state. After his wife's leaving, he encounters failure from his work and losses his house; he fights with a man to get a free bed for his son in the church; he sells blood to maintain life demands, and he runs hurriedly from the police station to the interview office of the Stock Exchange to get a job order... These are unimaginable obstacles he experiences during his life crisis.

When facing obstacles, a successful man may undoubtedly choose to fight against them. Fighting against fate is an irresistible part of people's life. Chris never gives up when confronted with life difficulties. He is persistent, so he never ceases his step towards the bright future. When he fails to raise his family, he spares no time to sell his machine. When his wife leaves him, he bears the pressure from family and work. He asks his son to stay with him and decides to take a new business as an intern with no salary. When he loses his house and the government confiscates his assets, he renews his vigor and gets rid of the cheating from life. All these fighting he makes in this crisis can ascribe to his life motivation. Generally speaking, behind the fighting behavior there always stand some motivations, pulling people to step further. These motivations can be classified into two types: inner motivation and outside motivation. The first kind of motivation is an inner one. Many people doubt why Chris Gardener makes a decisive choice when facing such a big life challenge. As a matter of fact, he holds a strong belief in mind. Liberty, equality and the pursuit of happiness are three essences of American life. Inspired by these three beliefs proposed in The Declaration of Independence, Chris learns to adapt himself to his life crisis. When he encounters failure, or even goes bankruptcy, those words written on 
The Declaration of Independence stand out in his mind—a call about freedom, equality and pursuit. In this film, a sentence in a church reads that "The important thing about that freedom train is that it is got to climb mountains, we all have to deal with mountains... Lord, do not let that mountain leave, give the strength to climb it...”. Besides, with his persistence, optimism and strong desire toward happiness, he is spurred to fight for his bright future. These motivations are the most natural elements to make him a real fighter against fate. Chris is at that time in the ebb of his life, and he sits in the church, listening to the song of god and reflecting his sorrows and expectations. We know that after that day in church, Chris's life begins to show a turning point. Therefore, Chris becomes a man with strong inner power. The next comes to outside motivation, which includes two aspects. Firstly, Chris Gardener's life is always beset with difficulties. Despite this, he still holds responsibility to his life. His responsibility for his family, especially to his beloved son is the prime power of his fighting (YANG, 2012). Being abandoned by his father in an early age, Chris is easy to be found that he is lacking in parental love. Therefore, he chooses to give all his love to his son to make sure little Gardener lives a happy life. From this film, it is obvious that in addition to those material devotions, Chris also attaches great importance to his son's moral development. He wants his son to know that accepting education is more important than playing basketball, but at the same time he didn’t force him to give up playing it. For Chris, his son's development is more important than anything. However, he knows that he must provide a basis for his son's further development. At least, he must get a job to support his son. Therefore, he determines to fight and spares no effort to get rid of his predicament. Another outside motivation is the American middle-level organization: stock trade company and the church. As Tamara says, because of the influence of industrialization, many social functions of family are shifted to other social organizations. In this film, despite race, gender and age, the stock company advocates equality, which refers to the equal opportunity of pursuing happiness and dream (LIU \& HUANG, 2014). It is this equal opportunity that sparks hope to Chris Gardener, a black man who comes from the lowest social ladder. Besides, the church also affords free accommodation for Chris, making him free from basic needs. In addition to the material support, the church in this film also provides mental support for Chris. Furthermore, in American society, the government provides free service for those people in need. That is why Chris can get a free place to sleep when he goes bankruptcy. These help many people out of desperation, and also instill people with motivation to pull themselves together again.

From the above, a general understanding of the key to Chris's success becomes available. This paper prefers to put more emphasis on Chris's personal efforts, because it is his inner wealth and under no circumstance can other people change it.

\section{Significance of Individual and Social Development Drawn From Chris's Unyielding Spirits}

This film is a typical motivational one, with the great investment expert Chris Gardener as its main character. Therefore, it stimulates every ordinary man in real life to achieve their individual development. Besides, reflections about social development can also be presented to Chinese.

As for individual development, Chris Gardner says in his autobiography: "I had got through many sufferings, darkness and fear in my first twenty years, but I never give up” (Gardner, 2010). When happiness comes close to people, many of them may easily miss the chance to catch it. For those weak people, they tend to be afraid of failure, while for those people with strong determination, they choose to fight against fate and pursue their dreams. Chris is a lucky guy. He is adept at dealing with things like numbers and social interaction, and he knows how to arrange his own life. Most importantly, he is always responsible for his life. The Pursuit 
of Happyness is not only just a film, but a true story which happens on a real man, and gives people enlightenment on how to tackle problems with unyielding spirits when they are in dilemma. In such a society with fierce competition, people's pressure increases with the rapid development of society. Therefore, learning to adapt to the social pressure is a big test for people, especially for those from the low social ladder. From this film, people can get the knowledge of how to survive the difficulty and become successful. First of all, people should hold dream tightly and keep going on. Chance never comes back for the second time to your life, and the only thing you can do is to seize it tightly once you meet it. Secondly, people need to be optimistic. It is an all-known fact that a depressive attitude always brings negative emotions. You are in fact a loser if you choose to surrender in front of negative emotions. At last, you should equip yourself with solid social skills, which will become your potential assets of becoming a winner. These elements can surely be conducive to individual development. Individual development may make people conjure up three essences of American Dream: “independent motivation, free choice and self-fulfillment”. Thus, American people think that every man, with his own determination, can create a bright future from a lower part to the top of his life. A classic American Dream can be explained as a happy, prosperous way of life, achievable to anyone in the United States who works hard. As an important part of American social value system, the American Dream is a popular item among people. James Truslow Adams first used the word "American Dream" in his book The Epic of America which was written in 1931 (Truslow, 1931). Since its founding in 1776, America has presented itself as an empire of liberty and prosperity. Since then, the true meaning of American Dream varies from time to time. Despite this, "desire and pursuit" and "equality and freedom" are always indispensable parts of American Dream. Chris had once corrected the word written on the wall of his son's kid garden: There is no "Y" in happyness, it is an "I" (YAN \& HU, 2008). This is an implication that people should not complain about their wretched life when coming across difficulties, they need to make their own efforts to pursue their happiness.

Apart from individual development, American Dream and its social value present people another angle to appreciate the film. When people talk about American Dream, they always have a common mode to realize it (YANG, 2012). In order to realize the dream, people need to give highlight to the four features related to American Dream so as to get some reflections for the Chinese dream. Firstly, the main character is always an ordinary people. The soul of American Dream endows every citizen with equal opportunity. Every man has his own right to pursue dream, and the society attaches great importance to individualism. Chris is undoubtedly to be an insignificant part of American society. When he falls into the hell of life, he thinks of Thomas Jefferson's The Declaration of Independence, in which there are descriptions about the right to live, to get freedom and happiness. And it is from this declaration that he finally finds the truth of American Dream: Happiness will never come close to you unless you yourself value the opportunity to create your own wonder. The second feature of American Dream is self-fulfillment. American's behavior orientation is deeply influenced by Christianity. In the 1620s, the puritans established their colony on the land of America by taking the boat of Mayflower (YANG, 2012). They believed in the accumulation of wealth and respect the spirit of independence. In the film, the proverb which is told by Chris shows Puritanism: God helps those who help themselves. Thirdly, the main character has his potential of realizing his dream. For example, Chris is goal-oriented, good with numbers and good with people, and also, he is optimistic. All these are Chris's advantages, which become an instrument for his success. The last feature of American Dream is that it always ends up with a happy ending. Chris Gardener's life may be filled with twists and turns, but through his own fighting, he gets his final success. That is a typical example of the fulfillment of American Dream. These features do give us enlightenment when 
we are dealing with things in China. Since American Dream is the essence of America, the grasp of its features can enlighten Chinese people about how to fight against their life and be independent to settle life problems. The truth is that in China, fierce competition shows its appearance everywhere. In addition to the policy support from the government and the social welfare, people also need to have a belief that they can finally pursue success by counting on themselves when dealing with difficulties. Most importantly, they need to have unyielding spirits against fate even if they are in the deepest part of darkness. China's prosperity has strongly proved that Chinese, who have an incomparable courage and spirit, can finally shake off poverty and become prosperous.

\section{Conclusion}

The Pursuit of Happyness is not just an emotionally stimulating film. It is also a thought-provoking one. This paper gives reflections to both Chinese individuals and the whole society. Individuals need to have a deep reflection on the film's background, the main character's personality charm, his secrets of success as well as the practical significance of his unyielding spirits. The society, including the government and the social welfare, should support everyone so as to make a more stable and harmonious living environment.

\section{References}

Adams, J. T. (1980). The epic of America. New York: Greenwood Press.

BAO, X. L. (2013). Analysis of the spiritual orientation of inspiring movies in US from The Pursuit of Happyness. Film Literature, 05, 081-082.

GAO, G. L. (2010). Valiant of adversity_Enlightenment on the spirit of main character in Robinson Crusoe and The Pursuit of Happyness. Journal of Chifeng Institute, 11, 84-85.

Gardner, C. (2010). The pursuit of happyness. Beijing: Tsinghua University Press.

GUO, S. L., \& WANG, C. (2010). Review of The Pursuit of Happyness. Movie Review, 15, 114-115.

Jefferson, T. (1776). The declaration of independence.

LI, X. J. (2012). Seek hope in despair-Understanding of the The Pursuit of Happyness. Journal of Jilin Institute of Chemical Technology, 08, 183-184.

LIU, J., \& HUANG, Q. L. (2014). American Dream in cracks-On the function of The Pursuit of Happyness and social middle organization. News World, 01, 137-138.

PAN, W. (2008). When life is in a mess-Analysis on the topic of The Pursuit of Happyness. Movie Review, 19, 54-55.

PANG, Y. (2013). On the main character's success in The Pursuit of Happyness. Film Literature, 20, 120-121.

WANG, P. J. (2011). Analysis on the characterization style in American inspirational movie-A case study on The Pursuit of Happyness. Film Literature, 12, 112-113.

XU, J. J. (2013). Struggle in extreme situations-Understanding of Chris's pursuit of happiness in The Pursuit of Happyness. Movie Literature, 10, 098-099.

YAN, Y. Y., \& HU, R. G. (2008). American behavior-Cultural interpretation of The Pursuit of Happyness. Movie Literature, 21, 74-75.

YANG, M. (2012). Model of realizing American Dream—Analysis on The Pursuit of Happyness. Movie Literature, $21,75-76$. 